\title{
Oor feekse en hellevë̈ on shrews and harridans
}

\author{
Gerhard B van Huyssteen en Roald Eiselen \\ Sentrum vir Tekstegnologie (CTexT) \\ Noordwes-Universiteit \\ Potchefstroom \\ Suid-Afrika \\ E-pos: gerhard.vanhuyssteen@nwu.ac.za \\ E-pos:roald.eiselen@nwu.ac.za
}

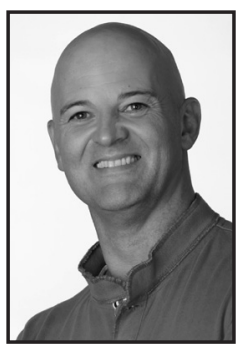

Gerhard van

Huyssteen

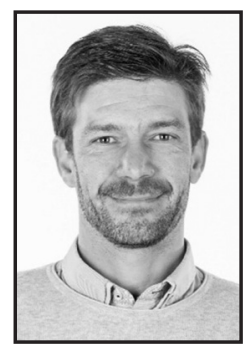

Roald Eiselen
Gerhard van Huyssteen is professor in Afrikaanse taalkunde en rekenaarlinguistiek aan die Noordwes-Universiteit. Hy dien sedert 2005 op die Taalkommissie van die Suid-Afrikaanse Akademie vir Wetenskap en Kuns; vanaf 2013 tree hy op as voorsitter van dié liggaam. Vanaf 2009-2014 dien hy op die paneel van mensetaaltegnologiekundiges van die Departement Kuns en Kultuur. Hy is ontvanger van die Elizabeth Eybers-beurs, die CL Engelbrecht-prys vir taalkundenavorsing vir sy aandeel in die publikasie van die tiende uitgawe van die Afrikaanse Woordelys en Spelreëls, en ontvanger van die Stalsprys vir inter- en multidissiplinêre navorsing. Benewens navorsing oor Afrikaanse morfologie en mensetaaltegnologie, hou hy hom die afgelope paar jaar ook besig met multidissiplinêre navorsing oor taaltaboes, spesifiek in Afrikaans en ander tale in Afrikaans se ekosisteem.

ROALD EISELEN is ' $n$ senior onderwerpspesialis in rekenaarlinguistiek aan die NoordwesUniversiteit. Van 2005-2013 werk hy by Microsoft se natuurlike-taalprosesseringsgroep, waarna hy na die Sentrum vir Tekstegnologie (CTexT) as senior lektor terugkeer. Vanaf 2017-2019 werk hy as stigterslid en tegniese bestuurder by die Suid-Afrikaanse Sentrum vir Digitale Taal-
Gerhard van Huyssteen is professor of Afrikaans linguistics and computational linguistics at the North-West University. $\mathrm{He}$ became a member of the Language Commission (Taalkommissie) of the SAAWK in 2005 and has been serving as the chairperson of this commission since 2013. He served as a member of the Department of Arts and Culture's panel of human language technology experts from 2009 to 2014. He was awarded the Elizabeth Eybers bursary, and the CL Engelbrecht prize for linguistics research for his contribution to the publication of the tenth edition of the Afrikaanse Woordelys en Spelreëls, and he was the recipient of the Stals prize for inter- and multidisciplinary research. Apart from research on Afrikaans morphology and human language technology, he is also busy with multidisciplinary research on linguistic taboos, specifically in Afrikaans and other languages in the Afrikaans ecosystem.

RoALD EISELEN is a senior subject specialist in computational linguistics at the North-West University. He worked at Microsoft's natural language processing group from 2005 to 2013, after which he returned to the Centre for Text Technology (CTexT) as a senior lecturer. He was a founding member and technical manager of the South African Centre for Digital Language Re-

\section{Datums:}

Ontvang: 2021-09-14

Goedgekeur: 2021-09-22

Gepubliseer: Desember 2021 
hulpbronne (SADiLaR), waartydens hy ook dien op die SABS se tegniese komitee 37. Sy primêre navorsingsfokusareas is masjienleer, en kerntegnologie- en taalhulpbronontwikkeling vir die inheemse Suid-Afrikaanse tale. Hy het al meer as 20 sagtewareprodukte en meer as 80 taalhulpbronne vir die Suid-Afrikaanse tale vrygestel. sources (SADiLaR) from 2017 to 2019. During this time, he also served on the SABS's technical committee 37 . His primary research focus areas are machine learning and core technology and resource development for the indigenous South African languages. He has released more than 20 software products and more than 80 linguistic resources for the South African languages.

\section{ABSTRACT}

\section{On shrews and harridans}

Research on swearwords (used here as a hyperonym to include other phenomena and/or synonyms, including cursing, cussing, profanity and foul language) has been done internationally for many years in a variety of scientific disciplines. In contrast, very little to no research has been done on swearing in the South African context. In this article, two research questions on two specific Afrikaans swearwords, feeks and helleveeg, are answered, viz.:

1. What does the constructionalisation network of the words feeks (shrew) and helleveeg (harridan) look like?; and

2. What are users'opinions about feeks and helleveeg, with specific reference to selfreported frequencies, taboo values, prominence, and gender connotation of the referents?

Since the Etimologiewoordeboek van Afrikaans (EWA) ("Etymology Dictionary of Afrikaans") was published in 2008, a number of newer etymological sources (such as the Etymologiewoordenboek van het Nederlands) have been added to Afrikaans linguists' arsenal of sources. With the help of this new information, as well as information from other sources, we are able to lay out clear constructionalisation paths for feeks and helleveeg. One of the interesting new insights is that these words have the same Proto-Indo-European stem, but that they came via different routes firstly to Dutch, and then to Afrikaans.

We also make a number of suggestions for visual representations of constructionalisation networks. We argue that end-users still need to be consulted about the intelligibility of our proposed visual representations, for example whether information should be presented from present to past, or vice versa. We also argue that solutions (such as those from EtymologyExplorer) should be found that would allow such visual representations to be automatically scaled to larger data sets.

Regarding the second question, we use data collected via short, online polls, as well as related sample sign tests, to compare the similarities and differences of people's perceptions about feeks and helleveeg. We show that these two words differ statistically significantly with respect to the following aspects:

- Self-reported frequency (production and perception): Feeks is said/written/heard/ read more often than helleveeg;

- Emotional valency: Feeks is more negatively charged than helleveeg;

- $\quad$ Salience: Feeks is less salient than helleveeg;

- Familiarity: Feeks is better known than helleveeg; and 
- Gender connotation: Feeks can only be used to refer to women, while helleveeg might also be used to refer to men.

If we compare each of the two words in terms of self-reported production and perception on the one hand, and their taboo values for the self and for others on the other hand, then we conclude that respondents think that:

- they themselves rarely use feeks, but they still encounter it more frequently (statistically significantly);

- they use helleveeg very seldom, and also encounter it very seldom; and

- $\quad$ both feeks and helleveeg are more offensive to other people than to themselves.

The article concludes with a number of pertinent questions for ongoing and future research.

KEYWORDS: $\quad$ choice model; constructicography; constructionalisation; corpus linguistics; etymology; "feeks"; frequency; "helleveeg", lexicology; network; opinion poll; related samples sign test; synonym; taboo value; usage-based

TREFWOORDE: etimologie; feeks; frekwensie; gebruiksgebaseerd; helleveeg; keusemodel; korpuslinguistiek; konstruksionalisering; konstruktikografie; leksikologie; meningspeiling; netwerk; sinoniem; taboewaarde; tekentoets vir verbandhoudende steekproewe

\section{OPSOMMING}

Navorsing oor vloekwoorde (hier gebruik as 'n hiperoniem om ander verskynsels en/of sinonieme in te sluit, waaronder swets, skel, (gods)laster en vuil taal) word al internasionaal vir baie jare in 'n verskeidenheid wetenskaplike dissiplines gedoen. Daarteenoor is daar baie min tot geen navorsing oor vloek in die Suid-Afrikaanse konteks gedoen nie. In hierdie artikel word twee navorsingsvrae oor twee spesifieke vloekwoorde, feeks en helleveeg, beantwoord, te wete:

1. Hoe lyk die konstruksionaliseringsnetwerk van feeks en helleveeg?

2. Wat is gebruikers se opinie oor feeks en helleveeg, met spesifieke verwysing na selfgerapporteerde frekwensies (sowel produksie (sê/skryf), as persepsie (hoor/lees)); die taboewaarde (d.i. aanstootlikheid vir self en vir ander); persepsie oor die prominensie (d.i. emosiebelaaidheid, opvallendheid en bekendheid); en die geslagskonnotasie van die referent van dié twee woorde?

Resente insigte in die etimologie van feeks en helleveeg word in detail bespreek, terwyl voorstelle vir visuele voorstellings van etimologiese inligting en konstruksionaliseringsnetwerke aan die hand gedoen word. Daar word ook uitvoerig gerapporteer oor 'n persepsieondersoek wat met behulp van aanlyn vraelyste oor dié twee woorde gedoen is. Met behulp van 'n tekentoets vir verbandhoudende steekproewe, word die verskillende dimensies van die twee woorde met mekaar vergelyk. Die artikel sluit af met 'n vooruitskouing op toekomswerk.

\section{Inleiding}

As deel van die Woordeboek van die Afrikaanse Taal (WAT) se 95ste bestaansjaarvieringe in 2021, en as deel van hulle Borg 'n Woord-veldtog, het die Buro van die WAT verskeie openbare figure genooi om 'n woord te borg. Elke persoon moes dan 'n kort motivering skryf waarom s/hy die spesifieke woord gekies het. Een van die deelnemers was die bekende Afrikaanse 
skrywer Riana Scheepers, wat die woord feeks geborg het. Haar motivering word in Figuur 1 weergegee.

Die WAT is 95! Vier saam met ons die rykheid, verskeidenheid en relevansie van Afrikaans.

\section{SKRYWER}

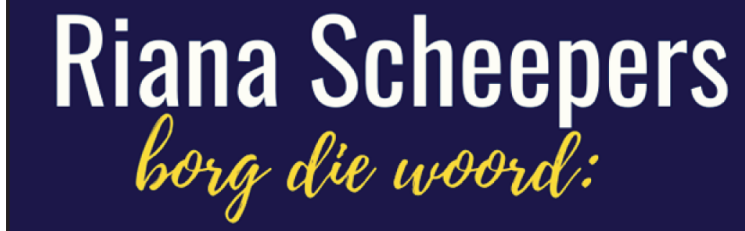

\section{feeks}

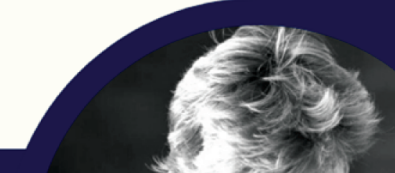

Die woord is die titel van een van my kortverhaalbundels. Die woord "feeks" word grootliks beskou as 'n skeldwoord, 'n woord om 'n bepaalde soort vrou te beledig en te verkleineer. Mense reageer ook sonder uitsondering emosioneel op dié woord. Vir my is dit 'n woord met verstommende dimensies en evokatiewe lading. Die woord is 'n sametrekking van die woord "Fee" (wat meestal positief, magies geïnterpreteer word) en "Heks" (wat meestal 'n negatiewe, boosaardige betekenislading het). Vir my persoonlik sê die woord "feeks" dat elke vrou iets van 'n fee, en iets van 'n heks in haar het. En dat vroue met' $n$ uitsonderlike sterk persoonlikheid gewoonlik as 'n feeks uitgekryt word.

Die Woordeboek van die Afrikaanse Taal vier vanjaar sy 95 ste bestaansjaar. Dra by tot die vaslegging van Afrikaans deur ook ' $n$ woord te borg of te koop. Besoek wat.co.za.

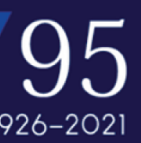

Figuur 1: Riana Scheepers se motivering vir die woord "feeks"

In 'n persoonlike telefoongesprek met Scheepers op 9 Junie 2021 bevestig sy dat haar etimologiese uitleg van feeks haar eie geestesproduk is: Dit is hoe sý die woord interpreteer en beleef, hoe sy wil hê die woord tot lewe moes gekom het. Sy as skrywer gun haar die kreatiewe vryheid om binne die konteks van die Borg 'n Woord-veldtog doelbewus 'n volksetimologie te skep, ten einde iets oor haar eie siening van vroue en vrouwees weer te gee.

Hierdie volksetimologie van Scheepers het direk aanleiding tot hierdie artikel gegee: Steek daar dalk enige waarheid in haar uitleg? Indien nie, waar kom feeks dan wel vandaan? Watter ander woorde is deel van feeks se woordfamilie? Wat is die etimologie van 'n sinoniem soos helleveeg (Luther et al., 2015)? Is feeks en helleveeg skelname; so ja, wat is hulle taboewaarde? En is dit woorde wat slegs op vroue van toepassing is, of kan hulle ook manlike of ander referente hê? 
Die doel van hierdie artikel is om antwoorde op hierdie vrae te verskaf, en meer spesifiek:

1. Etimologieondersoek: Hoe lyk die konstruksionaliseringsnetwerk van feeks en helleveeg?

2. Persepsieondersoek: Wat is gebruikers se opinie oor feeks en helleveeg, met spesifieke verwysing na die:

a. selfgerapporteerde frekwensie (produksie (sê/skryf) en persepsie (hoor/lees));

b. taboewaarde (d.i. aanstootlikheid vir self en vir ander);

c. prominensie (d.i. emosiebelaaidheid, opvallendheid en bekendheid); en

d. geslagskonnotasie van die referent

van dié woorde?

Hierdie twee aspekte van die woorde is verskillende, nieverbandhoudende inligtingskomponente (d.i. onderafdelings) van 'n tipe vloekwoordeboek, die sogenaamde Afrikaanse Vloekepedia, wat tans ontwikkel word. In die eerste afdeling word daarom 'n bondige kontekstualisering van die navorsing gegee, met spesifieke aandag aan konstruktikografie en die skep van hierdie Afrikaanse vloekkonstruktikon (die Vloekepedia). In die daaropvolgende afdeling word resente insigte in die etimologie van feeks en helleveeg in detail bespreek, en die afdeling word afgesluit met voorstelle vir visuele voorstellings van etimologiese inligting en konstruksionaliseringsnetwerke in die Vloekepedia. Die afdeling daarna se fokus is op 'n persepsieondersoek wat met behulp van aanlyn vraelyste oor dié twee woorde gedoen is; die analise word met behulp van 'n tekentoets vir verbandhoudende steekproewe gedoen. Dié gebruiksinligting sal ook uiteindelik in die Vloekepedia teregkom, byvoorbeeld om aan te toon wat die taboewaarde van 'n woord is. Die artikel sluit af met 'n vooruitskouing op toekomswerk.

Die wesensaard van hierdie artikel is beskrywend: Daar word nie gepoog om 'n teoretiese bydrae tot die konstruksiegrammatika, konstruktikografie en konstruksionaliseringsteorie te maak nie. Die artikel het daarom ook nie ten doel om hierdie teoretiese konsepte uit te lê en krities te oorweeg nie - kennis van en insig in die literatuur oor hierdie raamwerke word vooronderstel.

\section{Navorsingskonteks}

Die navorsing word uitgevoer binne 'n projek van die Noordwes-Universiteit (NWU) getiteld "Wat de Vloekwoord! Multidissiplinêre navorsing en wetenskapskommunikasie oor vloek". Navorsing oor vloekwoorde (hier gebruik as 'n hiperoniem om ander verskynsels en/of sinonieme in te sluit, waaronder swets, skel, (gods)laster, haatspraak, belediging, vulgariteit, taboetaal, ${ }^{1}$ en vuil taal) word al internasionaal vir baie jare in 'n verskeidenheid wetenskaplike dissiplines gedoen: literêre studies, joernalistiek en kommunikasiestudies, sielkunde, sosiologie, die regte, filosofie en etiek, kulturele antropologie en geskiedenis, pediatrie, neurologie en ander neurowetenskappe, en les bes, linguistiek. In die linguistiek word ook verskeie velde betrek: vergelykende etimologie, leksikologie en leksikografie, tipologie, grammatika, eersteen tweedetaalverwerwing, sosiolinguistiek en dialektologie, gebaretaal, kinetiek en rekenaarlinguistiek. Die grootste deel van die navorsingsliteratuur handel egter oor vloek in Engels, hoewel studies ook oor ander tale gedoen is, waaronder Deens, Fins, Frans, Italiaans, Japannees,

Daar sou motiverings vir twee skryfwyses kon wees, naamlik taboe taal ("taal wat taboe is") óf taboetaal ("taal wat 'n taboe is"); ons kies laasgenoemde, ter wille van eenvormigheid met taboewaarde ("waarde van die taboe").

Tydskrif vir Geesteswetenskappe, Jaargang 61 No. 4-1: Desember 2021 doi.10.17159/2224-7912/2021/v61n4-1a9 
Kantonees, Latyn, Nederlands, en Russies. Die titels van 'n paar standaard- en resente bronne dien ter illustrasie: The Oxford Handbook of Taboo Words and Language (Allan, 2019); Advances in swearing research: New languages and new contexts (Beers Fägersten \& Stapleton, 2017); Linguistic Taboo Revisited: Novel Insights from Cognitive Perspectives (Pizarro Pedraza, 2018); What the F-What swearing reveals about our language, our brains, and ourselves (Bergen, 2016); Why we curse: A neuro-psycho-social theory of speech (Jay, 2000); Nine nasty words: English in the gutter: then, now, and forever (McWhorter, 2021); Offensive Language: Taboo, offence and social control (O'Driscoll, 2020); en Rot lekker zelf op: Over politiek incorrect en ander ongepast taalgebruik (Van Sterkenburg, 2019).

Daarteenoor is daar baie min tot geen navorsing oor vloek in die Suid-Afrikaanse konteks gedoen nie, wat enigsins verbasend is, aangesien die gebruik van sekere vloekwoorde (spesifiek rassistiese skelwoorde) volgens die wet strafbaar is. Die meeste van die taalkundige navorsing het op die leksikografiese hantering van vloek gefokus (byvoorbeeld Dekker, 1991; Van Huyssteen, 1998), terwyl slegs 'n handjievol studies op grammatikale aspekte van vloek gefokus het (byvoorbeeld Calitz, 1979; Feinauer, 1981; Van Huyssteen, 1996). Onlangs het Van der Walt (2019) se MA-verhandeling aan die Noordwes-Universiteit (NWU) 'n afdeling oor vloekwoorde gehad as deel van haar ontleding van Zefrikaans ('n informele variëteit van Afrikaans). Op ander terreine was navorsing ook yl; byvoorbeeld, in Coetzee se 2018-artikel oor kinders se vloekgedrag in meertalige kontekste, is daar slegs drie verwysings na ander (sosio)linguistiese navorsing wat in die Suid-Afrikaanse konteks gedoen is.

Om hierdie leemte te vul, het ons begin met 'n multidissiplinêre projek wat sy primêre wortels in die digitale geesteswetenskappe het, en met insette van en implikasies vir (onder andere) taalkunde, letterkunde, kommunikasiestudies, neurologie, sielkunde, sosiologie, rekenaarwetenskappe en die regte. Hierdie projek (en spesifiek die onderwerp van vloek) het die potensiaal om insigte oor menslike kognisie en sosiale interaksie te bied, terwyl dit breedweg binne die kader van die Vierde Industriële Revolusie geplaas kan word. Die projek het in Julie 2019 begin, en die eerste wetenskaplike publikasies het in 2019 (Van Huyssteen, 2019) en 2021 (Eiselen \& Van Huyssteen, 2021; Van Huyssteen, 2021) verskyn.

In een van die subprojekte, Vloekepedia, word 'n gesaghebbende, navorsingsgebaseerde, gebruiksgebaseerde, ensiklopediese, aanlyn konstruktikon van Afrikaanse vloektaal ontwikkel. Die Vloekepedia word teoreties binne die kader van die kognitiewe konstruksiegrammatika geplaas, spesifiek as 'n konstruktikon, d.i. "a theoretical conception of language as a structured inventory of constructions, and ... a collection of construction descriptions, essentially a practical instantiation of the former concept" (Lyngfelt et al., 2018:1). So gesien is die Vloekepedia meer as net 'n vloekwoordeboek: Dit is 'n nuwerwetse manier om taal-in-gebruik op te teken, inklusief korpusvoorbeelde, taboe- morfologiese en sintaktiese konstruksies wat nie noodwendig taboewoorde bevat nie, frekwensiegebaseerde kollokasies, multimediaelemente, verbande met ander tale, etimologiese inligting, uitgebreide pragmatiese etikette, en so meer. Met betrekking tot feeks en helleveeg, is die fokus in hierdie artikel spesifiek op laasgenoemde twee aspekte.

\section{Etimologieondersoek}

Die Etimologiewoordeboek van Afrikaans (EWA; Liebenberg et al., 2003) bevat inskrywings vir beide die lemmas feeks (1) en helleveeg (2). Daarbenewens word beide woorde uitvoerig in talle Nederlandse etimologiewoordeboeke behandel (kyk etymologiebank.nl). 
(1) feeks s.nw.

Bitsige, nydige vrou.

Uit Ndl. feeks (1607) 'lastige vrou', eers uit die 17de eeu bekend, maar mntl. veel ouer.

Ndl. feeks met toegevoegde $-s$ uit Fries fekke, fikke, fikkert, mntl. te verbind met Oudsaksies fēkn, Oudhoogduits feihhan, Oudengels fācn 'lis, bedrog' en Oudnoors feikn 'ramp, verderf'.

Dial. D. feks 'sluwe, onsedelike vrou'.

Vgl. helleveeg.

(2) helleveeg s.nw.

Boosaardige, kwaai vrou.

Uit Ndl. helleveeg (1567), 'n samestelling van hel 'hel' en veeg 'flinke vrou'. Vgl. feeks.

'n Mens sou dan kon vra waarom verdere ondersoek in 'n wetenskaplike artikel nodig is. Onses insiens is daar ten minste twee potensiële aspekte wat met die oog op die saamstel van 'n Vloekepedia aandag sou kon kry, te wete korrektheid en volledigheid, en gebruikersvriendelikheid. Elk van dié aspekte word in die volgende subafdelings behandel.

\subsection{Korrektheid en volledigheid}

Enige woordeboekinskrywing is altyd aan verdere ondersoek onderworpe, hetsy om verandering in die taal by te werk (tipies in 'n standaardhandwoordeboek), of om nuwe kennis en insigte te inkorporeer (byvoorbeeld in 'n etimologiewoordeboek). Indien alle inligting by nadere ondersoek korrek en volledig blyk te wees, is daar natuurlik verder niks oor die betrokke inskrywing te sê nie.

EWA het in sy redaksionele beleid 'n doelbewuste (en geregverdigde, onses insiens) keuse gemaak met betrekking tot die hoeveelheid inligting wat aangebied word. Vir erfgoed word as ' $n$ reël slegs plaaslike ontwikkelinge aangedui, terug tot by die oorsprong in Nederlands; (2) is ' $n$ tipiese voorbeeld. Die veronderstelling is dat die geïnteresseerde leser dan verder in Nederlandse bronne sou kon gaan soek om meer inligting oor die voorgeskiedenis te kry, terwyl die "gewone gebruiker" (d.i. ander gebruikers as taalkundiges, leksikograwe of historici) nie oorlaai word met te veel inligting nie. Daar is natuurlik geen fout te vinde met so 'n redaksionele beleid nie, maar vir die Vloekepedia - wat júis ensiklopedies wil wees - is meer eerder as minder inligting wenslik.

EWA is nou byna 20 jaar gelede gepubliseer en word nie deurentyd met nuwe kennis en insigte bygewerk nie, waaronder byvoorbeeld dié in Philippa et al. (2003-2009) se Etymologisch Woordenboek van het Nederlands (EWN) wat ná EWA se publikasie verskyn het, of nuwerwetser bronne soos Wiktionary vir Engels (en.wiktionary.org), Nederlands (nl.wiktionary. org) en Afrikaans (af.wiktionary.org). Ook is daar in (1) én (2) inligting waarvan die korrektheid bevraagteken sou kon word, en aangesien EWA geen bronverwysings by inskrywings verskaf nie (anders as byvoorbeeld in Boshoff en Nienaber (1967) of De Vries (1971)), is dit ook nie moontlik om hulle bronne met nuwer bronne te vergelyk nie.

In Tabel 1 word 'n vergelyking getref tussen die inligting by die lemma feeks in onderskeidelik EWA en EWN; ooglopende verskille tussen hulle word in die EWA-kolom in vetdruk gemerk. Die volgende verskille is onses insiens wesenlik: 
- EWA dui aan dat die woord uit 1607 kom as feeks, terwyl EWN aandui dat dié spelling eers in die agtiende eeu verskyn het. Sterker nog, EWN gee ook 1607 as eerste optekening aan, maar dan eksplisiet met die spelling feex. Vir die navorser of geïnteresseerde persoon wat feeks se voorgeskiedenis wil naspeur, is hierdie inligting dus gewoon verkeerd.

- $\quad$ EWA dui aan dat feeks uit Fries kom. Behalwe vir die inskrywing in die Nederlandse Wiktionary wat hierdie standpunt ondersteun, is daar in geen ander bron op Etymologiebank.nl. sprake daarvan dat feeks uit Fries ontstaan het nie. De Vries (1971) sê: "wellicht uit fries fekke, fikke, fikkert, met toegevoegde s", wat 'n mens laat vermoed dat EWA hulle inligting hier gekry het, aangesien hulle ook verwys na "met toegevoegde -s". Wat egter oorgesien is deur EWA, is dat De Vries (1971) duidelik aandui dat dit móóntlik ("wellicht") uit Fries uit kom - nie definitief nie. Wat dié teorie egter waarskynlik op sy kop keer, is dat die aanlyn, gesaghebbende Wurdboek fan de Fryske taal (WFT; Van der Veen en Boer 1984-2010) by die lemma fekke onder "Etymologie" vermeld dat dié woord uit Nederlandse feeks ontstaan het (met datering 1900, en antedatering 1822 - twee honderd jaar ná die vroegste Nederlandse datering).

- EWA dateer nóg feeks, nóg helleveeg se eerste optekening in Afrikaans. Vir eersgenoemde vind ons 'n eerste leksikografiese bewerking pas in AWS (1931); laasgenoemde kon ons in 'n betekenisverklaring in SJ du Toit se Afrikaanse taalskat fan spreekwyse, gesegdes en uitdrukkings uit 1908 opspoor (Van der Merwe, 1971).

Die feit dat daar geen Nederlandse optekening voor die $17 \mathrm{e}$ eeu is nie, maak EWN se teorie dat dit 'n leenwoord uit Rynlands ( $F \bar{e} k s)$ is, des te aanneemliker, ook gegewe die gerekte uitspraak van die vokaal in Fêks. De Vries (1915) rekonstrueer oortuigend 'n Protogermaanse *faihiso ('vroulike bedrieër') by *faih ( 'vyandig'), via die Oudsaksiese fêkn ('boosaardigheid, bedrog') en ander vorme in Oudhoogduits, Oudengels, Oudnoors en Goties, asook Latyn en Oudiers (kyk Tabel 1).

Wat nóg in EWA, nóg in EWN verreken word, is die perspektief van die Woordenboek der Nederlandsche taal (WNT; De Vries et al., 1864-998). By die lemma feeks sê hulle dat dit blykbaar kom uit die stam van die Hoogduitse en Nederduitse (d.i. Platduitse) woorde wat by die lemma huikefaak vermeld word. By dié lemma word gesê dat faak(s) ('veragtelike persoon') die stam van onder andere die Nederlandse feeks en fikfakken ('om te gesel; om te bedrieg') is en dat dit verwant is aan die Hoogduitse fachs ('grap'), fächs of fäx ('grapmaker, swaap') en feix of veix ('onbeholpe persoon'). Dit is volgens die WNT ook verwant aan onder andere die Nederduitse feks (oftewel Fēks, soos hier bo bespreek) asook die Wesfaalse fiks ('veragtelike wese').

As ons dan $f a a k(s)$ as stam neem, dan sê die WNT by die lemma fikfakken dat dit teruggaan op die Middelnederduitse fickfacken ('om te bedrieg'), wat onder andere terug te vinde is in Schiller en Lübben (1875) as fickfacker en in Von Fallersleben (1845) as vikvacker. Van die Middelnederduits gaan ons dan terug op die Oudsaksiese fêkn (of fêkni 'vals; boos'; Köbler, 2014), en van daar af na De Vries (1915) se rekonstruksie van die Protogermaanse *faihiso ('vroulike bedrieër') by *faih ('vyandig'). Vanaf *faih neem EWA ons verder terug na die Proto-Indo-Europese *peig. of *peik. ('vyandiggesind') (Pokorny 1959). Die eenvoudigste etimologiese roete wat 'n mens dus sou kon loop, is: 
TABEL 1: $\quad$ Vergelyking van feeks in EWA (2003) en EWN (2003-2009)

\begin{tabular}{|c|c|c|}
\hline feeks & $E \boldsymbol{W A}$ & $E W N$ \\
\hline Woordsoort & selfstandige naamwoord & selfstandige naamwoord \\
\hline Betekenis & bitsige, nydige vrou & helleveeg, kreng \\
\hline Betekenisontwikkeling & - & lastige, opvlieënde vrou (1848) \\
\hline Antedatering & 1607 (Nederlands) & $\begin{array}{l}1607 \\
\text { (Vroegnieunederlands) }\end{array}$ \\
\hline Spelling van antedatering & feeks & $\begin{array}{l}\text { feex ("de spelling feeks ver- } \\
\text { schijnt pas in de } 18 \mathrm{e} \text { eeuw") }\end{array}$ \\
\hline Verbandhoudende woorde & $\begin{array}{l}\text { Dialekties Duitse } \boldsymbol{f e k s} \text { 'sluwe, } \\
\text { onsedelike vrou' }\end{array}$ & $\begin{array}{l}\text { - Friese fekke, fikke } \\
\text { - Groningse fikke } \\
\text { - Rynlandse dialektiese vorm } \\
\text { Fēks 'sluwe, onsedelike } \\
\text { vrou' }\end{array}$ \\
\hline Voorgeskiedenis & $\begin{array}{l}\text { - Moontlik veel ouer as } 17 \mathrm{e} \\
\text { eeu } \\
\text { - Die Nederlandse feeks met } \\
\text { toegevoegde } \cdot \text { s kom uit } \\
\text { Friese fekke,fikke,fikkert }\end{array}$ & $\begin{array}{l}\text { - } \text { Herkoms onseker } \\
\text { - Moontlik verbandhoudend } \\
\text { met Protogermaanse *faihiso } \\
\text { ('bedriegster'), wat verband } \\
\text { hou met *faih. 'vyandig', } \\
\text { soos in helleveeg (De Vries, } \\
\text { 1915) } \\
\text { - Die Protogermaanse *faih } \\
\text { · kom uit die Proto-Indo- } \\
\text { Europese wortel *peig., } \\
\text { *peik. 'vyandig' }\end{array}$ \\
\hline $\begin{array}{l}\text { Histories verbandhoudende } \\
\text { woorde }\end{array}$ & $\begin{array}{l}\text { Friese fekke, fikke, fikkert } \\
\text { hou verband met Ouds- } \\
\text { aksies fēkn, Oudhoogduits } \\
\text { feihhan, Oudengels fäcn } \\
\text { 'lis, bedrog' en Oudnoors } \\
\text { feikn 'ramp, verderf' }\end{array}$ & $\begin{array}{l}\text { Protogermaanse *faih · hou } \\
\text { verband met Oudsaksies } \\
\text { fêkn 'boosaardigheid, } \\
\text { bedrog'; Oudhoogduits } \\
\text { feihan 'id.'; Oudengels } \\
\text { fācen 'id.'; Oudnoors feikn } \\
\text { 'ramp, verderf'; Goties } \\
\text { bifaihōn 'bedrieg' } \\
\text { - Ook Latynse piger 'lui'; } \\
\text { Oudierse písuna } \\
\text { 'boosaardig, verraderlik' }\end{array}$ \\
\hline
\end{tabular}


feeks (Afrikaans) $<$ feex (Vroegnieunederlands) $<$ Fēks (Rynlands) $<$ faak $(s)$ (Middelnederduits) $<$ fékn (Oudsaksies) $<*$ faihiso (Protogermaans) $\approx *_{\text {faih }}$. (Protogermaans) < *peig of *peik (Proto-Indo-Europees)

Die etimologiese verbande tussen feeks en helleveeg is in EWA nie voor die hand liggend nie, aangesien EWA by die tradisie van onder meer De Vries (1971) en Van Wijk (1936 [1912]) aansluit, soos saamgevat kan word in die inskrywing in (2) hier bo. Die argument is basies dat 'n veeg 'n flink persoon is, en in samestelling met hel sou dit dui op iemand ('n vrou) wat verdien om die hel te vee. Van Wijk (1936 [1912]) sê dit klop met "ons taalgevoel" en dat die woord waarskynlik so geïnterpreteer is so lank as wat dit bestaan. Maar soos De Vries (1971), vind ons dit minder waarskynlik "wegens de sterk afwijkende betekenis" (vanaf die positiewe 'flink persoon', tot by die negatiewe 'boosaardige, kwaai vrou').

Veel aanneemliker lyk dus sy teorie (De Vries, 1971) dat die oorsprong daarvan in Middelnederlandse helletêve ('helhond') sou lê (kyk ook Van Wijk, 1936 [1912]), wat volgens hom náás hellefeeks bestaan het. Van Veen en Van der Sijs (1997) sluit hierby aan as hulle sê dat helletēve 'n sinoniem is van helleueghe (helleveeg), maar nié dat dit die oorsprong daarvan is nie. Hulle teorie is dat dit 'n Middelnederlandse kompositum uit 1567 is: helle ('hel') + vegen ('vyandig behandel'). Verwijs en Verdam (1885-929) dateer vegen tussen 1370 en 1378 en toon aan dat dit ook vete ('tradisionele vyandskap') ten gronde lê. Die stap vanaf vegen ('vyandig behandel') na De Vries (1915) se Protogermaanse *faih ('vyandig') en verder terug lyk vir ons veel waarskynliker as die teorie dat hierdie veeg na 'n flink persoon sou verwys, en ons kan dus die volgende etimologiese roete vir helleveeg konstrueer:

helleveeg (Afrikaans) $<$ helleveeg en helleueghe (Vroegnieunederlands) $<$ helle+vegen

(Middelnederlands) $<*_{\text {faih }}$ (Protogermaans) $<*^{*}$ peig of *peik (Proto-Indo-Europees)

Ons kan uit die etimologiese roetes van feeks en helleveeg nou 'n samehangende prentjie skets: Uit die Proto-Indo-Europese *peig of *peik. ('vyandiggesind') ontwikkel die Protogermaanse *faih ( 'vyandig'). In Middelnederlands lewer dit vegen ('vyandig behandel') op, terwyl die afleiding *faihiso ('vroulike bedrieër') in Middelnederduits faak(s) ('om te bedrieg') word. Via die een ontwikkelingsroete (Middelnederlands) kry ons die kompositum helle ('hel') + vegen ('vyandig behandel') wat later helleueghe en helleveeg in Vroegnieunederlands word, terwyl die ander ontwikkelingsroete (Middelnederduits) in Rynlands Fēks ('sluwe, onsedelike vrou') word en later geleen word as feex in Vroegnieunederlands. Ons kry dus in dieselfde periode 'n klompie woorde met ongeveer dieselfde betekenis wat mekaar as mikrokonstruksionaliserings (Traugott \& Trousdale, 2013) onderling versterk, naamlik helleteve, helleveeg/helleueghe, hellefeeks/-feex en feex. Afrikaans erf uiteindelik helleveeg en feeks by Vroegnieunederlands.

\subsection{Gebruikersvriendelikheid}

Selfs al sou ons wou glo dat die samevattende paragraaf aan die einde van die vorige afdeling helder en duidelik is, is en bly dit inligting wat waarskynlik nie geredelik toeganklik vir die deursneetaalgebruiker sal wees nie. Etimologiewoordeboeke is immers daarvoor berug dat dit dikwels vir die gewone gebruiker moeilik is om inligting uit die digte tekste te ontrafel. So byvoorbeeld bied etimologiewoordeboeke soms konstruksionaliseringsroetes vanaf die verlede tot en met die hede aan (byvoorbeeld die eerste paragraaf in die inskrywing van die lemma feeks in Philippa et al. (2003-2009) - kyk (3)), of andersins vanaf die hede teruglopend in tyd (byvoorbeeld die res van die inskrywing in (3)). Die tallose afkortings vir taalname en 
bronne, jaartalle, verskillende simbole (byvoorbeeld $<$ teenoor $\rightarrow$ ), spellingvariante van woorde, vreemde letters en alfabette, terminologie, ensovoorts, maak etimologiewoordeboeke des te meer besondere inligtingsdigte en moeilike tekste om te lees.

(3) feeks zn. 'helleveeg, kreng'

Vnnl. 'boosaardige vrouw' in de boze feex 'id.' [1607; WNT]; de spelling feeks verschijnt pas in de $18^{\mathrm{e}}$ eeuw. Tegenwoordig ook in verzwakte betekenis 'lastige, opvliegende vrouw' [1848; WNT].

Herkomst onduidelijk. Men denkt wel aan samenhang met Fries fekke, fikke 'id.' [1822] en Gronings fikke 'id.'. De Vries (1915) reconstrueert pgm. *faihiso 'bedriegster' (bij *faih- 'vijandig', zoals in $\rightarrow$ helleveeg), waaruit dan in het Duits, Fries en Nedersaksisch vormen met /ks/ verwacht worden; deze zijn echter geen van alle geattesteerd. Het Rijnlandse dialect kent echter wel Fēks 'sluwe, onzedelijke vrouw', zodat ontlening aan het Rijnlands tot de mogelijkheden behoort.

Bij pgm. *faih- 'vijandig' horen wellicht: os. fêkn 'boosaardigheid, bedrog'; ohd. feihan 'id.'; oe. fācen 'id.'; on. feikn 'ramp, bederf'; got. bifaihōn 'bedriegen'.

Met pgm *faih- zijn verwant: Latijn piger 'lui'; Oudiers písuna 'boosaardig, verraderlijk'; bij de wortel pie. *peig-, peik- 'vijandig' (IEW 795).

Lit.: W. de Vries (1915), 'Etymologische aanteekeningen: feeks', in: TNTL 34, 9; H.Fr. Rosenfeld (1956), 'Germ. Fis(t) in seiner Entfaltung in übertragenem Sinn', in: Beiträge zur Geschichte der deutschen Sprache und Literatur 78, 411-413

Verskeie woordeboeke, veral aanlyn woordeboeke, probeer toenemend om hierdie tipe inligting meer toeganklik te maak. So byvoorbeeld gebruik die aanlyn weergawe van die Oxford English Dictionary (www.oed.com) nie meer afkortings vir taalname nie, maar skryf die name uit; in Etymologiebank.nl word vol vorme van afkortings in mini-opwipvensters vertoon; Google vertoon gegenereerde grafiese voorstellings (kyk Figuur 2) in hulle woordeboekinligtingsboksies (research.google.com/bigpicture/dictionary.html); die Engelse Wiktionary (en. wiktionary.org) maak ruim van hiperteks gebruik, sodat 'n leser per woord kan deurklik na 'n volgende bladsy, eerder as wat alle inligting op een blad vertoon word.

\section{Oorsprong \\ FRENCH \\ haridelle $\longrightarrow$ harridan \\ old horse late 17 th century}

late 17 th century (originally slang): perhaps from French haridelle 'old horse'.

Gebruik met verloop van tyd vir: harridan

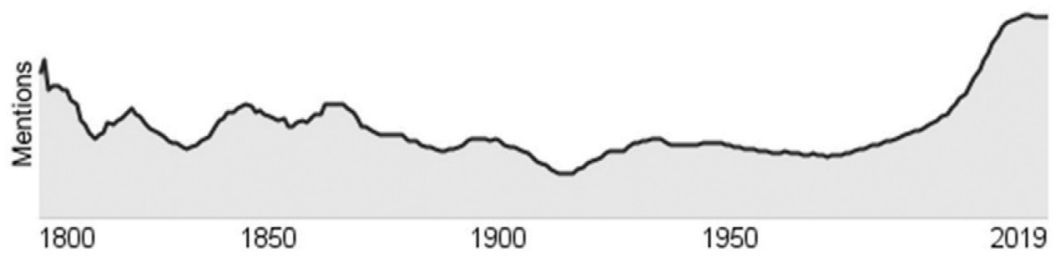

Figuur 2: $\quad$ Grafiese inligting by "harridan" (google.com) 
Gegewe die doelwit dat die Vloekepedia 'n omvattende aanlyn hulpbron sal wees (en dus nie aan die beperkinge van papier gebonde is nie), bestaan die geleentheid om allerlei inligting meer gebruikersvriendelik aan te bied. So byvoorbeeld sou die etimologiese inligting van (sommige) woorde visueel aangebied kon word, byvoorbeeld as konstruksionaliseringsnetwerke ("constructionalization networks").

Die konsep konstruksienetwerke (of konstruksionele netwerke; "constructional networks") is nie nuut in die kognitiewe linguistiek en spesifiek konstruksiegebaseerde benaderings tot die grammatika nie. Langacker (1987) se beskrywing van die grammatika as 'n "structured inventory of symbolic units" wat in dinamiese netwerke aan mekaar verbind is, word meer as 30 jaar later steeds as een van die basiese uitgangspunte van gebruiksgebaseerde konstruksiegrammatika beskou. Oor die afgelope dekade het die konsep konstruksionalisering ook deeglik posgevat in diachroniese konstruksiegrammatika (Colleman, 2015, 2016; Enghels \& Garachana Camarero, 2021; Hilpert, 2013; Traugott \& Trousdale, 2013).

Soos wat 'n mens konstruksienetwerke vir bepaalde woorde/konstruksies sou kon optrek, sou 'n mens onses insiens ook konstruksionaliseringsnetwerke kon saamstel om die ontwikkeling van konstruksies met verloop van tyd (dus met 'n tyddimensie as deel van die netwerk) aan te dui. Figuur 3 is 'n voorstelling van 'n moontlike konstruksionaliseringsnetwerk vir feeks en helleveeg, gebaseer op die inligting wat hier bo gebruik is. ${ }^{2}$ Aan die regterkant word verskillende tydstippe aangedui waarin die tipiese ontwikkelingsfases van Afrikaans se Germaanse stratum verdeel kan word, byvoorbeeld Vroegnieunederlands van 1500-1600, Middelnederlands van 1200-1500, Oudnederlands van 500-1200, ensovoorts. Gewone pyle dui op die rigting van verandering (d.i. konstruksionalisering), terwyl stippelpyle (indirekte) invloed (d.i. bronne vir analogisering, neoanalise en vestiging) aandui.

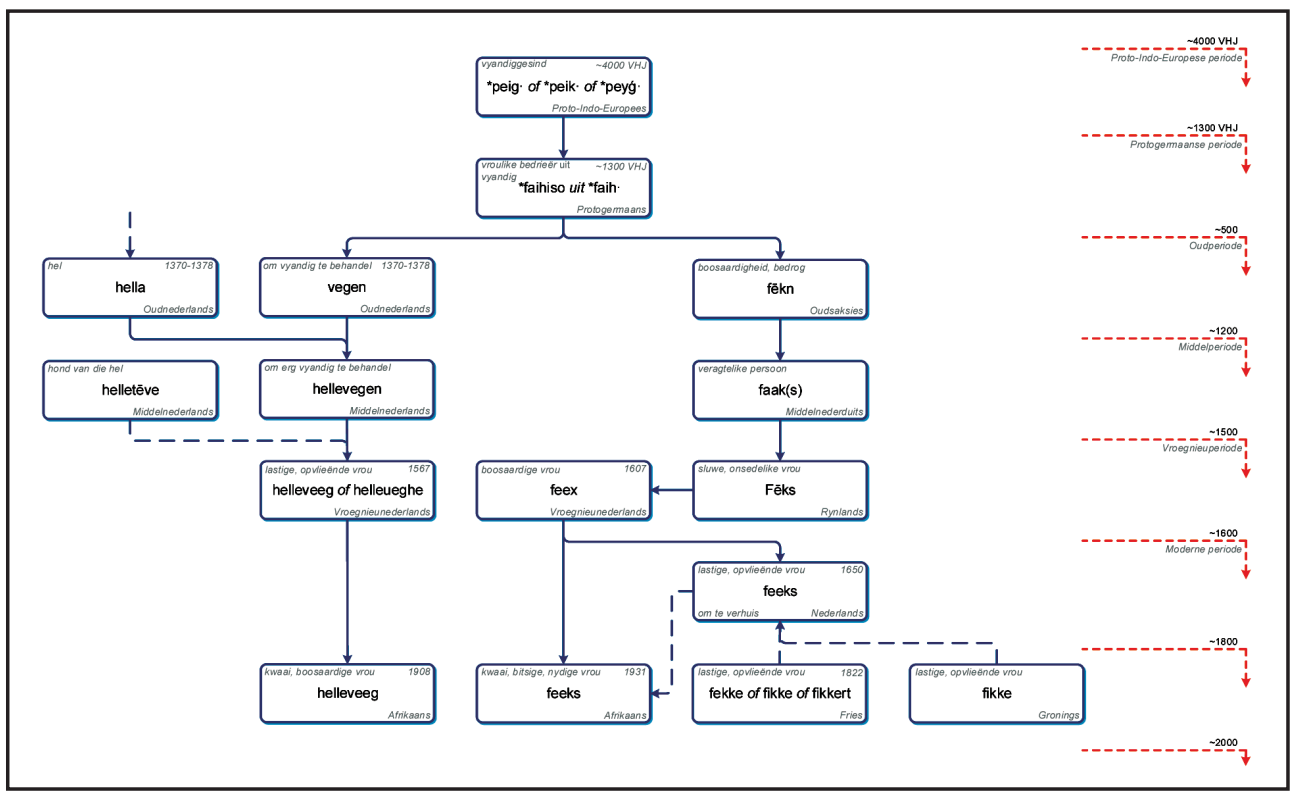

Figuur 3: Konstruksionaliseringsnetwerk van "feeks" en "helleveeg"

2 Ter wille van oorsigtelikheid word die redelik ingewikkelde en uitgebreide etimologie van hel nie in hierdie netwerk aangedui nie. 
Daar is onses insiens potensieel twee problematiese aspekte aan 'n voorstelling soos in Figuur 3. Aan die een kant kan so 'n konstruksionaliseringsnetwerk vir die gewone persoon (d.i. niespesialis) met 'n belangstelling in vloekwoorde dalk steeds te ingewikkeld, tegnies of abstrak wees. Om die inligting meer toeganklik en gebruikersvriendelik te maak, kan dit as eenvoudiger, populêrder etimologiese "padkaarte" aangebied word, soos in Figuur 4. In dié voorstellings word die inligting nie net visueel aantrekliker aangebied nie, maar word sommige aspekte van die inligting ook vereenvoudig (byvoorbeeld om diakritiese tekens by ouer tale te verwyder). Let ook daarop dat die voorstelling in Figuur 3 die ontwikkeling van verlede tot hede aanbied, terwyl dit in Figuur 4 andersom gedoen word (van hede tot verlede). Die keuse vir laasgenoemde is gebaseer op 'n informele vraag aan nege vriende en kollegas waar hulle hulle voorkeur moes aandui vir 'n voorstelling van hede tot verlede, of verlede tot hede. Sewe van die mense het aangedui dat hulle dit enigsins makliker vind om die inligting van hede tot verlede te interpreteer, maar niemand het besonders sterk daaroor gevoel nie. Dit is dus 'n aspek wat in die toekoms verder ondersoek kan word.

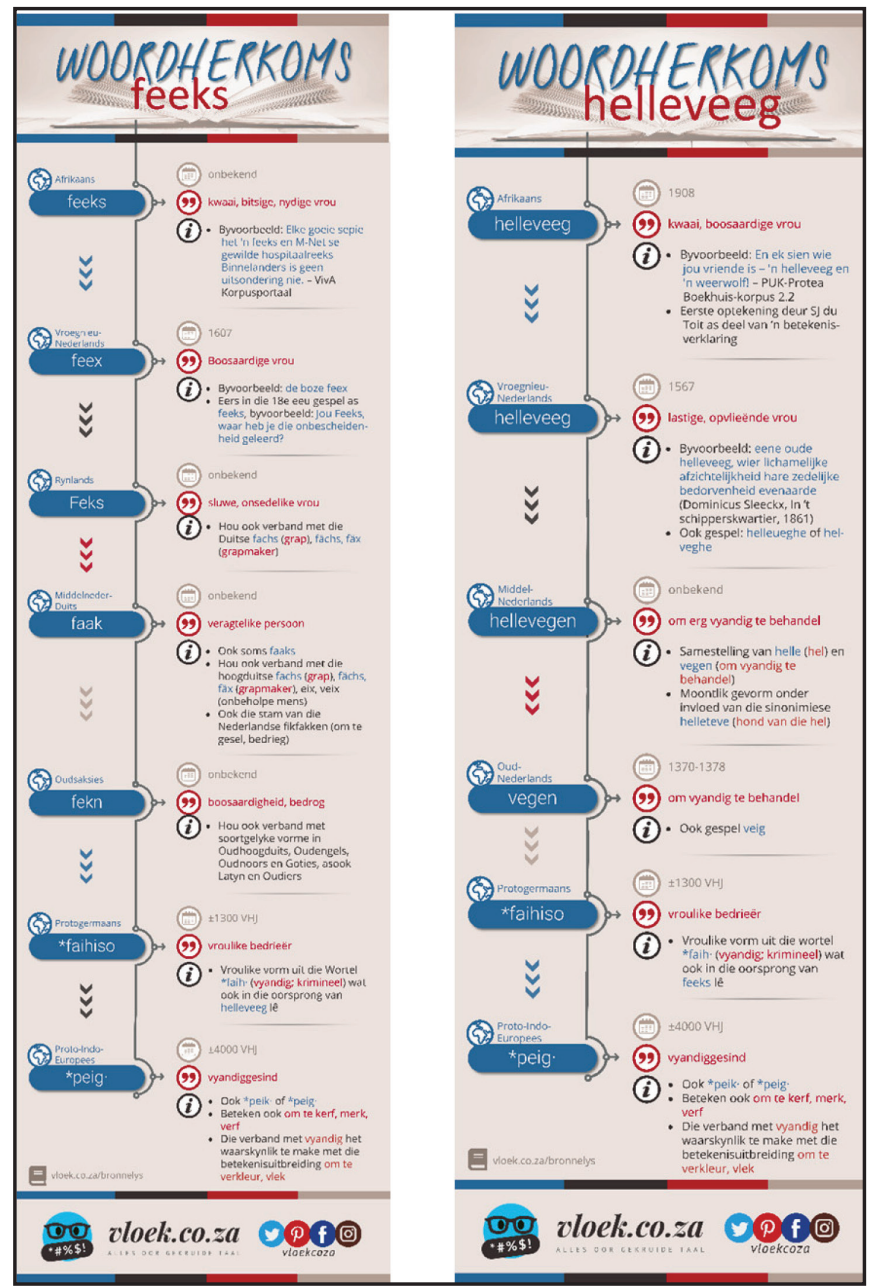

Figuur 4: Eenvoudiger etimologiese inligting vir "feeks" en "helleveeg" 
Die ander problematiese aspek het betrekking op die uitbreibaarheid van hierdie visuele voorstellings. Die uitbreibaarheid van enige visuele oplossing (d.i. "designing systems to handle large amounts of data gracefully"; Munzner, 2015:15), moet in gedagte gehou word wanneer dit vir ' $n$ bepaalde probleem voorgehou word. Veronderstel daar is 3000 inskrywings in die Vloekepedia, dan is dit ' $n$ haas onbegonne taak om sulke konstruksionaliseringsnetwerke handmatig vir elke inskrywing te teken - laat staan nog om dit elke keer wanneer nuwe inligting/insigte verkry word, by te werk. 'n Geoutomatiseerde benadering tot sulke leksikale data is dus eintlik 'n voorvereiste.

In dié verband lyk dit asof die benadering van EtymologyExplorer (etymologyexplorer. com) moontlik 'n oplossing kan bied. Deur gebruik te maak van natuurliketaalprosessering, diepmasjienleertegnieke en wolkrekenaartegnologie, gee hierdie mobiele toepassing visuele voorstellings van data wat oop en vrylik op Wiktionary beskikbaar is. Figuur 5 is 'n skermgreep van veechte, soos outomaties voorgestel in die toepassing. In oorleg met die ontwikkelaars van EtymologyExplorer sou 'n soortgelyke toepassing dus spesifiek vir die Vloekepedia gemaak kon word; dit is egter toekomsmusiek wat verder ondersoek moet word.

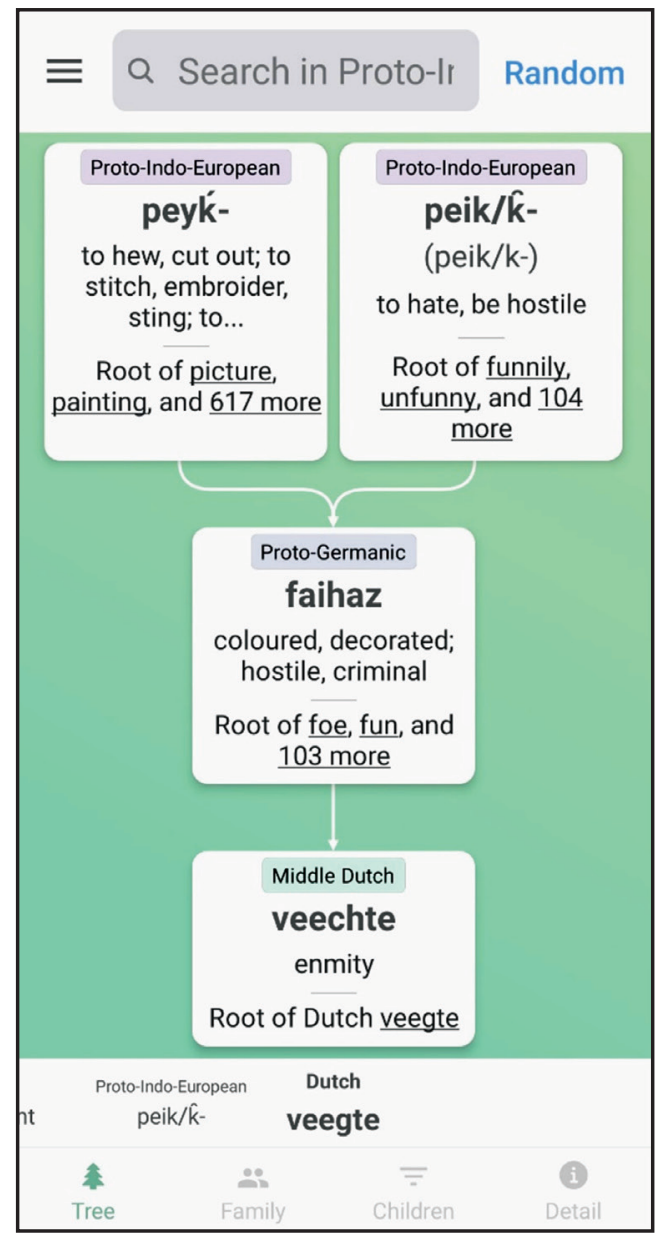

Figuur 5: $\quad$ EtymologyExplorer se voorstelling van "veechte" 


\section{Persepsieondersoek}

\subsection{Data-insameling}

Om gebruikersopinies oor vloekwoorde in te samel, word aanlyn meningspeilings van tyd tot tyd op die projekwebwerf, vloek.co.za, gepubliseer en via sosialemediaplatforms bekendgestel. Respondente registreer uit eie wil/belang op die webwerf wat deur middel van (sosiale) media en mondelinge metodes bemark word. ' $n$ Mens kan daarom aanvaar dat die steekproefmetode respondentgedrewe sal wees, soos uiteengesit en geformaliseer deur Heckathorn (1997). Die voordeel van hierdie benadering is dat dit toegang bied tot sogenaamde "verborge populasies", dit is respondente wat andersins nie bereid sou wees om aan navorsing oor vloek deel te neem nie.

Aangesien hierdie projek nie op besluitneming gerig is nie (soos om medisyne te toets, om te besluit oor sielkundige ingrepe, besluite oor produkte en pryse, ensovoorts), maar eerder op 'n beskrywing van die taalkundige (spesifiek leksikale) geleenthede en keuses van 'n geïnteresseerde groep mense, is statistiese verteenwoordigendheid nie 'n vereiste nie. Aktiewe stratifikasie van die respondentgroep is dus nie belangrik nie, aangesien bevindinge (byvoorbeeld opmerkings oor leksikale keuses) aan die betrokke groep gekoppel sal wees, ${ }^{3}$ sonder om na die algemene bevolking te ekstrapoleer (tensy die respondentgroep per abuis verteenwoordigend van die algemene bevolking is). Gevolglik is niewaarskynlikheidsbenaderings tot steekproefneming van respondente in orde, waarvan geleentheid-/gerieflikheidsteekproewe die bekendste is en wyd in soortgelyke taalkundige navorsing gebruik word (Rasinger, 2008).

Tydens registrasie moet geregistreerde gebruikers 23 demografiese vrae beantwoord; daarna hoef hulle nie weer vir elke woord dieselfde inligting te verskaf nie. Meningspeilings oor woorde kan daarom slegs deur geregistreerde gebruikers voltooi word. Aangesien daar nie in hierdie artikel van demografiese veranderlikes gebruik gemaak word nie, laat ons 'n bespreking van hierdie aspek van die navorsingsprojek daar.

Hoewel sulke kort meningspeilings verskeie voordele vir die respondente inhou (waarvan die belangrikste is dat dit nie te veel van hulle tyd op 'n slag opeis nie), is daar ook verskeie nadele aan hierdie benadering waarvan navorsers bewus moet wees. ${ }^{4} \mathrm{Die}$ een is dat meningspeilings vir verskillende woorde nie gelyktydig gedoen word nie, aangesien meningspeilings

3 Demografiese gegewens word nie in hierdie artikel as veranderlikes gebruik nie. Ter wille van volledigheid, word slegs enkele demografiese inligting van die oorvleuelende steekproefgroep $(N=94)$ hier gegee; persentasies word afgerond. Die groep bestaan uit $51 \%$ mans en $49 \%$ vroue; $83 \%$ van die respondente is jonger as 60 . Op een na het alle respondente aangedui dat hulle wit is. $75 \%$ van die respondente het 'n Baccalaureus-, honneurs-, meesters- of doktorsgraad, terwyl $70 \%$ van die respondente in die gerealiseerde of hoë middelklas is. Behalwe een Namibiër, woon al die respondente in Suid-Afrika, waarvan $51 \%$ in Gauteng woonagtig is.

4 Een van die sekondêre doelwitte van hierdie projek is juis om die wetenskaplike aanneemlikheid en geldigheid van die gebruik van kort, aanlyn meningspeilings (en baie kort meningsopnames) te ondersoek, veral in 'n poging om vraelysvoosheid te probeer bekamp. 'n Potensiële respondent moet as gebruiker op die webwerf vloek.co.za registreer en sy/haar basiese demografiese inligting (byvoorbeeld geslag, ouderdom, huistaal, kwalifikasies) invul as deel van sy/haar private profiel, terwyl ook eenmalig toestemming gegee word om aan die navorsingsprojek deel te neem. Vervolgens kan geregistreerde gebruikers deelneem aan kort, aanlyn meningspeilings (en meningsopnames) oor die onderwerp, sonder om telkens deur die moeisame proses te gaan om demografiese inligting te verskaf elke keer as 'n nuwe meningspeiling of meningsopname gepubliseer word.

Tydskrif vir Geesteswetenskappe, Jaargang 61 No. 4-1: Desember 2021 doi.10.17159/2224-7912/2021/v61n4-1a9 
vir individuele woorde met gereelde tussenposes op die webwerf gepubliseer word. Dit impliseer ook dat dieselfde gebruikers nie noodwendig die peilings vir verskillende woorde voltooi nie, wat kan lei tot verskeie ongelykhede in die onderskeie datastelle. Aangesien die peilings oop bly vir nuut geregistreerde gebruikers om ook te voltooi, kan die resultate ook mettertyd (effens) wissel.

Die peiling vir feeks is byvoorbeeld op 30 Maart 2020 vrygestel, en 183 respondente het tot en met 04 Augustus 2021 deelgeneem. In teenstelling hiermee is helleveeg se peiling op 11 April 2020 vrygestel, maar slegs 130 mense het tot en met 04 Augustus 2021 daarop gereageer. Toe ons egter op 01 Julie 2021 die data afgelaai het vir doeleindes van hierdie artikel, was daar vir feeks nog slegs 151 respondente en vir helleveeg slegs 99 respondente; ons gebruik die data soos op 01 Julie 2021 in die res van hierdie artikel. Waar ons feeks en helleveeg met mekaar vergelyk, gebruik ons slegs die antwoorde van mense wat aan beide peilings deelgeneem het, vir 'n totaal van 94 respondente. Vir die vergelykings tussen verbandhoudende vrae gebruik ons egter al die data vir elke woord (feeks: $N=151$; helleveeg: $N=99$ ). In toekomstige navorsing sal ons ook statistiese metodes ondersoek om ongelykwaardige datastelle soos hierdie met mekaar te vergelyk.

Om taboewaardes vir Afrikaanse woorde te verkry, volg ons breedweg die metodiek van Beers Fägersten (2007, 2012). Anders as Beers Fägersten wat 'n 10-punt- Likertagtige skaal vir woordgraderings gebruik het, volg ons Jay (1992) in die gebruik van 'n 9-punt- Likertagtige skaal, waar slegs die tellings aan die twee uiterste eindes beskrywend gekategoriseer word. Dit versterk die idee dat daar gelyke afstande tussen elke punt op die skaal is (Endresen \& Janda, 2017). Respondente word in elke meningspeiling (kyk Figuur 6 vir 'n voorbeeld) versoek om hul uitsprake oor elk van die volgende agt vrae in vier kategorieë te rapporteer:

\section{Selfgerapporteerde frekwensie}

1. Hoe gereeld sê of skryf jy die woord? (Glad nie ... Baie) (produksie)

2. Hoe gereeld hoor of lees jy die woord? (Glad nie ... Baie) (persepsie)

\section{Taboewaarde}

3. Hoe aanstootlik vind jy die woord persoonlik? (Glad nie ... Baie)

4. Hoe taboe of sosiaal onaanvaarbaar is die woord vir mense in die algemeen? (Glad nie ... Baie)

\section{Prominensie}

5. In watter mate is die woord vir jou emosioneel gelaai? (Baie negatief ... Baie positief)

6. Hoe prominent is die woord? (Glad nie ... Baie)

7. Hoe goed weet jy wat die woord beteken? (Glad nie ... Baie goed)

\section{Geslagskonnotasie van referent}

8. Word die woord slegs vir mans, mans en vroue, of slegs vroue gebruik? (Slegs mans ... Slegs vroue) 


\section{:ạ: "helleveeg"}

Die onderstaande vrae handel oor die woord helleveeg, soos byvoorbeeld in: Sy is ' $n$ helleveeg.

Hoe gereeld gebruik jy self die woord as jy praat of skryf? *

Gebruik die skuiwer of klik/tik op die skal om jou keuse aan te dui

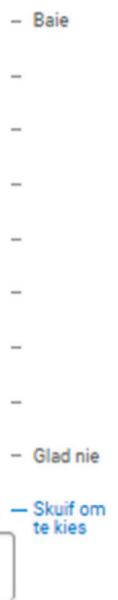

Hoe gereeld hoor of lees jy die woord? (Byvoorbeeld in gesprekke, oor die radio, op TV, in tydskrifte, boeke, die internet, ens.) *

Gebruik die skuiwer of klik/tik op die skal om jou keuse aan te dui

$$
\begin{aligned}
& - \text { Baie } \\
& - \\
& - \\
& - \\
& - \\
& - \\
& - \\
& - \\
& - \text { Glad nie } \\
& \text { - Skuif om } \\
& \text { tekies }
\end{aligned}
$$

Figuur 6: $\quad$ Voorbeeld van eerste twee vrae in 'n meningspeiling 


\subsection{Data-analise}

Aangesien die data nie normaal versprei is nie, kan geen van die statistiese toetse wat 'n normaalverspreiding vooronderstel, gebruik word nie. Twee toetse wat van toepassing is op ordinale data waar 'n normaalverspreiding nie vereis word nie, is Wilcoxon se rangtekentoets (WRTT) en die tekentoets vir verbandhoudende steekproewe (VSTT). Hierdie twee toetse deel die volgende eienskappe:

- Vir elkeen van die vrae word die waardes van een antwoordstel van die ander afgetrek (byvoorbeeld persoon A se response op feeks by vraag 1, minus persoon A se respons op helleveeg by vraag 1) om die verskil tussen die antwoordstelle te kry. Slegs hierdie verskilwaardes word vir die statistiese analises gebruik.

- Die mediaan is die puntwaarde waar die een helfte van die verskilwaardes groter as die mediaanwaarde is en die ander helfte kleiner as die mediaanwaarde is. Dit is nie noodwendig dieselfde as die gemiddeld van die verskilwaardes nie.

- Beide hierdie toetse bepaal of daar 'n statisties beduidende verskil $(p<0.05)$ tussen die twee antwoordstelle se verskilwaardes is.

- Nulhipotese $\left(H_{0}\right)$ : Die mediaan van verskille tussen die waardes van die afhanklike veranderlike is gelyk aan nul.

- Indien daar 'n statisties beduidende onderskeid tussen die verskilverspreiding is, word die nulhipotese verwerp (met ander woorde dat die mediaan van verskille tussen die waardes nie gelyk aan nul is nie).

Daar is egter ook belangrike verskille tussen die twee toetse:

- WRTT neem die werklike verskil tussen respondente se antwoorde in ag, terwyl VSTT slegs in ag neem of die verskil positief of negatief is (met ander woorde nie die grootte van die verskil nie).

- WRTT vereis dat die verspreiding van verskille simmetries om die mediaan moet wees, terwyl VSTT geen sulke vereistes/aannames het nie.

- $\quad$ WRTT het daarom eintlik meer beskrywingskrag as VSTT.

Aangesien geen van ons datastelle hierdie verspreidingsaanname van WSTT nakom nie, het ons geen ander keuse om deurgaans VSTT te gebruik nie. Dit is wel enigsins interessant om op te merk dat die statistiese beduidendheid van die WRTT's presies dieselfde as dié van die VSTT's is, ten spyte van die feit dat die aanname van WRTT nie nagekom is nie. Die rede hiervoor sou in toekomstige navorsing verder ondersoek kon word. (Hier onder rapporteer ons telkens die $z$ - en p-waardes van beide toetse.)

Gegewe ons datastelle vir twee woorde (feeks en helleveeg) met agt vrae in vier kategorieë oor elk, doen ons twee stelle vergelykings:

a. Vergelyking tussen feeks en helleveeg van die antwoorde op dieselfde vrae (byvoorbeeld of daar 'n verskil is tussen feeks se emosiebelaaidheid en helleveeg se emosiebelaaidheid).

b. Vergelyking van die antwoorde op verbandhoudende vrae binne 'n enkele woord (byvoorbeeld of daar 'n verskil is tussen die selfgerapporteerde frekwensie vir sê/ skryf teenoor hoor/lees by feeks); dit word slegs vir die selfgerapporteerde frekwensies en die taboewaardes gedoen. 


\subsection{Resultate: feeks vs. helleveeg}

Die resultate van hierdie gedeelte word in Figuur 7 opgesom. Die besonderhede word in die hieropvolgende subafdelings bespreek.

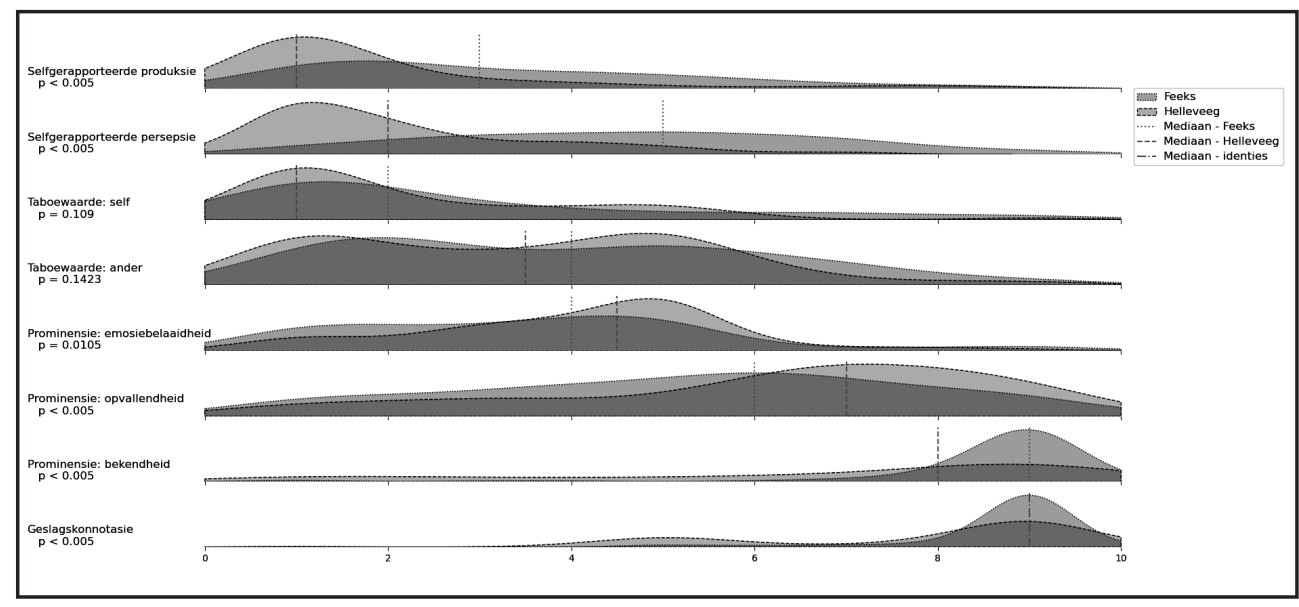

Figuur 7: Resultate van "feeks" vs. "helleveeg"

\subsubsection{Selfgerapporteerde frekwensie: produksie}

'n VSTT is gedoen om te bepaal of daar 'n verskil in die selfgerapporteerde produksie (d.i. sê en skryf) van feeks en helleveeg is. As ons die nege opsies op die Likertskaal in drie groepe verdeel (min, gemiddeld, baie), dan het $59.1 \%$ van die respondente aangedui dat hulle feeks min gebruik (dus opsies 1 tot 3 ); hiervan het $23.4 \%$ van die totale getal respondente opsie 1 ("nooit") gekies. In teenstelling hiermee het $85.1 \%$ van respondente aangedui dat hulle die woord helleveeg min (opsies 1 tot 3) gebruik, waarvan 67\% van die totaal gesê het dat hulle dit nooit gebruik nie. Daar is 'n statisties beduidende verskil in die mediaan van die verskille tussen die gebruik vanfeeks teenoor helleveeg, en ons kan dus die nulhipotese verwerp (VSTT: $z=-5.139, p<0.005$; WRTT: $z=-4.948, p<0.005)$. Die selfgerapporteerde gebruik van helleveeg is dus baie laer as feeks.

\subsubsection{Selfgerapporteerde frekwensie: persepsie}

'n VSTT is gedoen om te bepaal of daar 'n verskil in die selfgerapporteerde persepsie (d.i. hoor en lees) van feeks en helleveeg is in die media wat die respondent gebruik. Hier het 33\% van die respondente aangedui dat hulle feeks min teëkom (opsies 1 tot 3), met 7\% van die totaal wat aangedui het dat hulle nooit die woord lees of hoor nie. $45.7 \%$ het aangedui dat hulle dit gemiddeld (opsies 4 tot 6) teëkom, terwyl 22.3\% meen dat hulle dit baie (opsies 7 tot 9) hoor of lees.

Helleveeg word baie minder gehoor en gelees, met $80.9 \%$ van die respondente wat aangedui het dat hulle dit min hoor of lees, waarvan $47.9 \%$ van die totaal dit nooit teëkom nie. Slegs $2.1 \%$ van die respondente het aangedui dat hulle dit baie gereeld hoor of lees (opsies 7 tot 9), 
maar niemand het opsies 8 of 9 gekies nie. Dit is dus duidelik dat helleveeg nie 'n woord is wat die respondente baie hoor of lees nie.

Ook hier is daar 'n statisties beduidende verskil in die mediaan van verskille tussen feeks en helleveeg, en die nulhipotese kan insgelyks verwerp word (VSTT: $z=-8.162, p<0.005$; WRTT: $z=-7.590, p<0.005)$.

\subsubsection{Taboewaarde: self}

Om te bepaal of daar 'n verskil in die taboewaarde van feeks en helleveeg vir die respondente self is, is 'n VSTT ook gedoen. Feeks blyk nie vreeslik aanstootlik vir die respondente te wees nie, aangesien $72.3 \%$ aangedui het dat die woord min aanstoot gee (opsies 1 tot 3 ), met $44.7 \%$ van die totale getal respondente wat opsie 1 ("glad nie") gekies het. Slegs $12.8 \%$ van die respondente het aangedui dat die woord meer as gemiddeld aanstootlik is (opsies 7 tot 9).

Soortgelyk aan feeks, word helleveeg nie as aanstootlik gesien nie, met $75.5 \%$ wat min aandui (opsies 1 tot 3 ) en 55.3\% wat sê dit is glad nie vir hulle aanstootlik nie (opsie 1). Slegs twee respondente $(2.1 \%)$ het aangedui dat die woord baie aanstootlik is (opsie 9); niemand het opsie 7 of 8 gekies nie.

In hierdie geval is daar nie 'n statisties beduidende verskil in die mediaan van verskille tussen die aanstootlikheid van feeks teenoor helleveeg nie, en die nulhipotese kan nie verwerp word nie (VSTT: $z=-1.905, p=0.057$; WRTT: $z=-1.603, p=0.109$ ).

\subsubsection{Taboewaarde: ander}

Ten opsigte van die aanstootlikheid van feeks vir ander persone, toon die meerderheid respondente ook aan dat die woord nie werklik as aanstootlik gesien kan word nie: $47.9 \%$ van die respondente kies opsies 1 tot 3, waarvan $16 \%$ van die totale getal respondente sê dat die woord glad nie aanstootlik (opsie 1) vir ander is nie. Slegs $14.9 \%$ van die respondente het in hierdie geval opsies 7 tot 9 gekies.

Soortgelyk dui 50\% van die respondente aan dat helleveeg vir ander mense min aanstootlik is (opsies 1 tot 3), met $27.7 \%$ van die totaal wat aandui dat dit glad nie aanstootlik is nie. Slegs $5.3 \%$ dui aan dat helleveeg baie aanstootlik is (opsies 7 tot 9).

Die VSTT toon aan dat daar nie 'n statisties beduidende verskil in die mediaan van verskille tussen die aanstootlikheid van feeks teenoor helleveeg is nie (VSTT: $z=-1.661, p=0.097$; WRTT: $z=-1.467, p=0.142$ ). Die nulhipotese kan dus nie verwerp word nie.

\subsubsection{Persepsie: Emosiebelaaidheid}

Emosiebelaaidheid gaan oor die mate waartoe 'n woord negatief (opsies 1 tot 3), gemiddeld (opsies 4 tot 6), of positief (opsies 7 tot 9) gelaai is. Die emosiebelaaidheid van feeks word grotendeels as negatief gesien, met $46.8 \%$ van die respondente wat die woord as negatief sien en 'n verdere $45.8 \%$ wat die woord as gemiddeld gelaaid sien. Slegs sewe respondente $(7.4 \%)$ dui aan dat feeks positief gelaaid is.

Helleveeg word aansienlik positiewer deur die respondente ervaar: 33\% van respondente merk helleveeg as negatief, maar die meerderheid (61.7\%) kies gemiddeld (opsies 4 tot 6). Soortgelyk aan feeks, sien 'n baie klein persentasie (5.3\%) die woord as positief.

'n VSTT dui aan dat daar 'n statisties beduidende verskil in die mediaan van verskille tussen die emosiebelaaidheid van feeks teenoor helleveeg is (VSTT: $z=2.384, p=0.017$; WRTT: $z=2.560, p=0.010)$. Die nulhipotese kan daarom verwerp word. 


\subsubsection{Persepsie: Opvallendheid}

Feeks word grotendeels as meer (opsies 7 tot 9) eerder as minder (opsies 1 tot 3) opvallend gesien, hoewel daar 'n eenvormiger verspreiding oor die skaal (van 1 tot 9 ) is. $24.5 \%$ van die respondente sien feeks as minder opvallend, 43.6\% sien die woord as gemiddeld opvallend, en die oorblywende $31.9 \%$ sien die woord as meer opvallend.

In teenstelling met feeks, word helleveeg duidelik as meer opvallend gesien, met $63.8 \%$ van die respondente wat helleveeg as meer opvallend beskou. 45 van die respondente (d.i. $47.9 \%$ van die totale getal respondente) ervaar die woord selfs as baie opvallend (opsie 9).

Ook in hierdie geval kan die nulhipotese met behulp van die VSTT verwerp word. Daar is 'n statisties beduidende verskil in die mediaan van verskille tussen die emosiebelaaidheid van feeks teenoor helleveeg (VSTT: $z=3.276, p=0.001$; WRTT: $z=3.166, p=0.002$ ). Hieruit sou 'n mens al kon vermoed dat die opvallender woord (helleveeg) minder bekend is as die onopvallender woord (feeks), soos inderdaad ook in die volgende afdeling bevestig word.

\subsubsection{Persepsie: Bekendheid}

'n VSTT bevestig inderdaad dat daar 'n statisties beduidende verskil in die mediaan van verskille tussen die bekendheid van feeks teenoor helleveeg is (VSTT: $z=-5.543, p<0.005$; WRTT: $z=-5.359, p<0.005)$, sodat die nulhipotese verwerp kan word. Feeks is volgens die respondente 'n bekender woord (opsies 7 tot 9), met $81.9 \%$ van respondente wat aandui dat hulle baie (opsie 9) bekend met die woord is. Slegs vyf (5.3\%) van die respondente dui aan dat die woord nie vir hulle baie bekend is nie (opsies 1 tot 6 ).

Hoewel die meerderheid respondente $(63.8 \%)$ aandui dat hulle goed bekend is met helleveeg (opsies 7 tot 9), is daar wel 11.7\% van respondente wat aandui dat hulle glad nie (opsie 1) bekend is met die woord nie. 'n Totaal van $21.3 \%$ van die respondente dui aan dat hulle nie eintlik juis bekend met die woord is nie (opsies 1 tot 3 ).

\subsubsection{Persepsie: Geslagskonnotasie}

Word die woorde feeks en helleveeg meestal gebruik om na vroue te verwys, of kan 'n man ook 'n feeks of helleveeg genoem word? Die oorgrote meerderheid respondente $(85.1 \%)$ dui aan dat feeks uitsluitlik na vroue verwys (opsie 9). Slegs een respondent het aangedui dat dit uitsluitlik vir mans gebruik word. Hoewel die meerderheid van respondente aandui dat helleveeg uitsluitlik vir vroue gebruik word (62.8\% kies opsie 9) en $72.3 \%$ dat dit grotendeels na vroue verwys (opsies 7 tot 9), is daar verbasend genoeg 'n redelik groterige groep respondente (26.6\%) wat aandui dat 'n man én vrou 'n helleveeg kan wees (opsies 4 tot 6).

Met behulp van 'n VSTT kan ons inderdaad ook hierdie nulhipotese verwerp. Daar is 'n statisties beduidende verskil in die mediaan van verskille tussen die geslagskonnotasie vir feeks teenoor helleveeg (VSTT: $z=-3.944, p<0.005$; WRTT: $z=-4.026, p<0.005$ ).

\subsection{Resultate: verbandhoudende vrae}

Die tweede tipe vergelyking wat ons doen, is 'n vergelyking van die selfgerapporteerde frekwensie vir sê/skryf (produksie) teenoor hoor/lees (persepsie) by feeks en helleveeg onderskeidelik, asook die taboewaardes vir die respondente self teenoor dié vir ander mense vir elk van die twee woorde. Die volgende vrae word dus vir elke woord gestel: 
a) Sê/skryf die respondente woord X meer as wat hulle die woord hoor/lees?

b) Is woord $\mathrm{X}$ meer taboe vir respondente self as wat hulle dink dit vir ander mense is?

Anders as by die vergelykings van die twee woorde met mekaar, waar slegs die response van respondente gebruik kon word wat vrae vir beide feeks en helleveeg beantwoord het $(N=94 ;)$, kan al die respondente wat onderskeidelik feeks $(N=151)$ en helleveeg $(N=99)$ se vrae beantwoord het, ingesluit word in die onderstaande analises. Figuur 8 gee 'n opsomming van die resultate soos dit in besonderhede in die onderstaande subafdelings bespreek word.

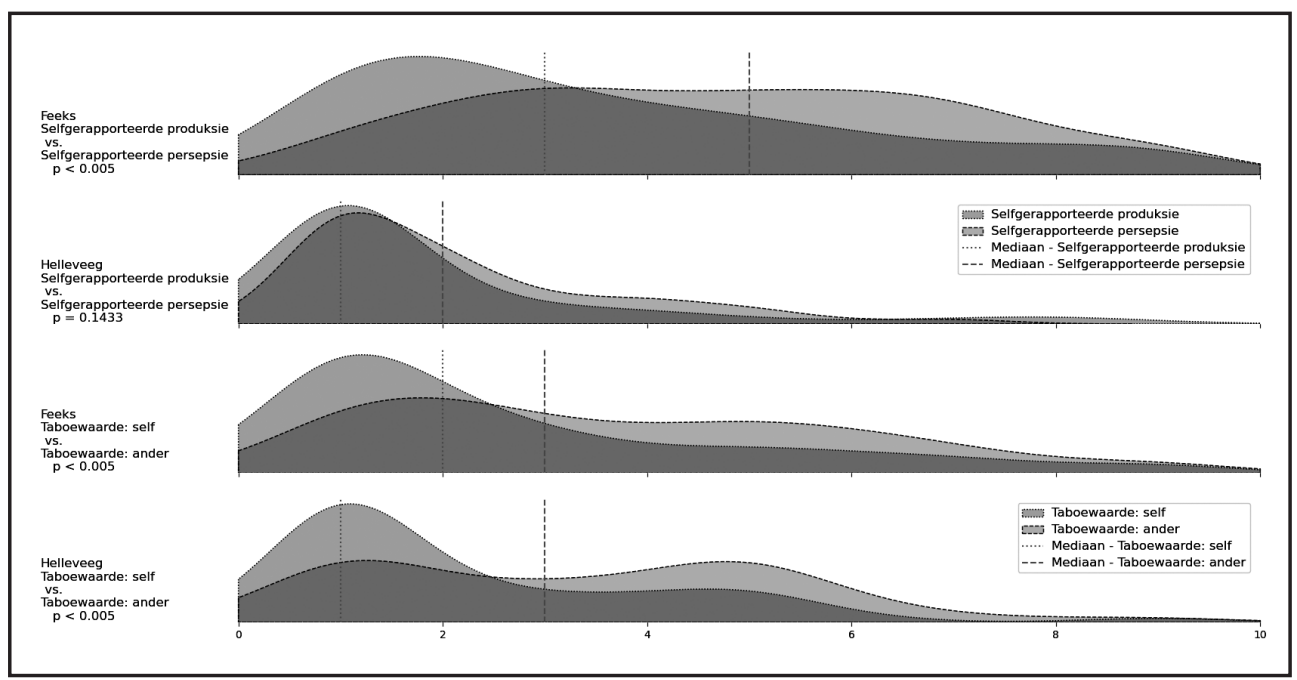

Figuur 8: Resultate van verwante vrae by "feeks" en "helleveeg"

\subsubsection{Selfgerapporteerde frekwensie: produksie vs. persepsie}

\section{Feeks}

'n VSTT is gedoen om te bepaal of daar 'n verskil is in hoe gereeld respondente dink hulle die woord feeks sê of skryf, teenoor hoe gereeld hulle dink hulle die woord hoor of lees. Die meerderheid van die respondente $(59.6 \%)$ het aangedui dat hulle feeks min gebruik (opsies 1 tot 3); slegs $8.5 \%$ dink hulle gebruik die woord baie (opsies 7 tot 9). In teenstelling hiermee, dui $45.7 \%$ van die respondente aan dat hulle dink dat hulle feeks tog wel met 'n gemiddelde frekwensie hoor en lees (opsies 4 tot 6), maar daar is steeds 'n groot groep (33\%) wat die woord min teëkom (opsies 1 tot 3).

Die VSTT toon aan dat daar 'n statisties beduidende verskil in die mediaan van verskille tussen die selfgerapporteerde frekwensie van produksie teenoor persepsie is (VSTT: $z=5.953$, $p<0.005$; WRTT: $z=6.066, p<0.005$ ). Die nulhipotese kan dus verwerp word, sodat ons tot die gevolgtrekking kom dat respondente dink dat hulle die woord meer hoor en lees as wat hulle dit self sê of skryf. 


\section{Helleveeg}

Nog 'n groter deel van die respondente (85.1\%) dui aan dat hulle helleveeg min (opsies 1 tot 3 ) self sê of skryf, terwyl slegs ses respondente (6.4\%) beweer dat hulle die woord meer gereeld gebruik. Hulle dui insgelyks aan dat hulle die woord min hoor of lees $(80.9 \%)$, met slegs twee persone $(2 \%)$ wat meen hulle kom die woord enigsins meer gereeld (opsie 7$)$ teë. Niemand het opsie 8 of 9 ("baie gereeld") gekies nie.

Anders as by feeks kan die nulhipotese in hierdie geval nie verwerp word nie. Aangesien daar nie 'n statisties beduidende verskil in die mediaan van verskille tussen produksie teenoor persepsie is nie (VSTT: $z=1.960, p=0.050$; WRTT: $z=1.464, p<0.143$ ), kan ons tot die gevolgtrekking kom dat respondente helleveeg min self gebruik en teëkom.

\subsubsection{Taboewaarde: self vs. ander}

\section{Feeks}

Feeks word oor die algemeen nie as baie aanstootlik deur respondente self ervaar nie, met $72.3 \%$ van die respondente wat die woord as minder aanstootlik (opsies 1 tot 3 ) ervaar. Slegs $12.8 \%$ van die respondente vind feeks meer as gemiddeld aanstootlik (opsies 7 tot 9). Respondente se persepsie van hoe ander mense die woord ervaar, is egter wel anders as hul eie ervaring daarvan. Hoewel $47.9 \%$ van die respondente steeds aandui dat feeks as minder aanstootlik deur ander ervaar behoort te word (opsie 1 tot 3 ), is daar 'n groterige groep (37.2\%) wat dink dat 'n mens tog versigtig met die woord moet omgaan (opsies 4 tot 6). Daar is egter ook baie min respondente (14.9\%) wat dink dat feeks meer as gemiddeld aanstootlik vir ander mense kan wees.

Dit blyk inderdaad met behulp van 'n VSTT dat die nulhipotese verwerp kan word. Daar is ' $n$ statisties beduidende verskil in die mediaan van verskille tussen die taboewaarde vir die self teenoor vir ander mense (VSTT: $z=5.818, p<0.005$; WRTT: $z=5.535, p<0.005$ ).

\section{Helleveeg}

Soos vir die ander gevalle is 'n VSTT ook gebruik om te bepaal of daar 'n verskil is in die taboewaarde vir die self teenoor dié vir ander vir die woord helleveeg. Ook hier kan die nulhipotese verwerp word, aangesien daar 'n statisties beduidende verskil in die mediaan van verskille tussen eie taboewaarde en taboewaarde vir ander is (VSTT: $z=4.286, p<0.005$; WRTT: $z=5.187, p<0.005$ ).

Soortgelyk aan feeks, sien respondente nie self helleveeg as 'n besonder aanstootlike woord nie, met $75.5 \%$ van die respondente wat aandui dat die woord hulle min aanstoot gee (opsies 1 tot 3 ). Slegs twee respondente (2\%) dui aan dat die woord baie aanstootlik (opsie 9) vir hulle is, maar niemand kies opsies 7 of 8 nie.

Die siening van ander se persepsie oor die taboewaarde van helleveeg, word soos by feeks ook meer konserwatief ingeskat: Slegs $50.0 \%$ van die respondente dink dat ander mense die woord as minder aanstootlik sal ervaar. $44.7 \%$ van die respondente dink ander mense ervaar helleveeg as gemiddeld aanstootlik (opsies 4 tot 6), en 'n klein persentasie (5.3\%) van die respondente dink ander mense ervaar helleveeg meer as gemiddeld aanstootlik. 
In hierdie artikel wou ons antwoorde op twee spesifieke vrae verskaf:

\section{Hoe lyk die konstruksionaliseringsnetwerk van feeks en helleveeg?}

Sedert die EWA in 2008 verskyn het, is 'n aantal nuwer etimologiese bronne (soos die EWN) tot Afrikaanse taalkundiges se arsenaal van bronne toegevoeg. Aan die hand van hierdie nuwe inligting, asook inligting uit ander bronne, kon ons duidelike ontwikkelingsroetes virfeeks en helleveeg uitlê. Een van die interessante nuwe insigte is dat dié woorde dieselfde Proto-Indo-Europese stam het, maar dat hulle via verskillende roetes eers in Nederlands en daarna in Afrikaans tereg gekom het. Ons het ook 'n aantal voorstelle vir visuele voorstellings van konstruksionaliseringsnetwerke gemaak. Daar is aangetoon dat eindgebruikers nog geraadpleeg moet word oor die verstaanbaarheid van sulke voorstellings, byvoorbeeld of inligting van hede tot verlede aangebied moet word, of juis andersom. Ons het ook geargumenteer dat oplossings (soos dié van EtymologyExplorer) gevind moet word wat dit moontlik sal maak om die visuele voorstellings outomaties na meer data uit te brei.

2. Wat is gebruikers se opinie oor feeks en helleveeg, met spesifieke verwysing na selfgerapporteerde frekwensies, taboewaardes, prominensie en geslagskonnotasie van die referente?

Aan die hand van data wat via kort, aanlyn meningspeilings ingesamel is, en deur gebruik te maak van VSTT's, kon ons die ooreenkomste en verskille van mense se persepsies oor feeks en helleveeg met mekaar vergelyk. Ons het aangetoon dat hulle statisties beduidend van mekaar verskil ten aansien van die volgende aspekte:

- $\quad$ Selfgerapporteerde frekwensie (produksie en persepsie): Feeks word meer gesê/skryf/-hoor/-lees as helleveeg;

- Emosiebelaaidheid: Feeks is negatiewer as helleveeg gelaai;

- Opvallendheid: Feeks is minder opvallend as helleveeg;

- Bekendheid: Feeks is bekender as helleveeg; en

- Geslagskonnotasie: Feeks kan slegs vir vroue gebruik word, terwyl helleveeg dalk ook vir mans gebruik sou kon word.

As ons per woord die produksie en persepsie, en die taboewaarde vir die self en vir ander met mekaar vergelyk, dan sien ons dat respondente meen dat:

- $\quad$ hulle selffeeks min gebruik, maar dit tog meer gereeld teëkom;

- $\quad$ hulle helleveeg min gebruik en min teëkom;

- $\quad$ beide feeks en helleveeg aanstootliker vir ander mense is as vir hulle self.

Hoewel hierdie resultate op sigself interessant is, is die vrae vir toekomstige navorsing (oor ander woorde) selfs interessanter, byvoorbeeld:

- Is die VSTT 'n gepaste statistiese toets om hierdie tipe data mee te analiseer? Waarom is die statistiese beduidendheid van die WSTT telkens presies dieselfde as dié van die VSTT, ten spyte van die feit dat die aanname van WSTT nie nagekom is nie?

- Is daar metodes (byvoorbeeld statistiese toetse) wat 'n mens kan gebruik om datastelle te vergelyk met ongelykhede (soos byvoorbeeld meer respondente vir 
woord $\mathrm{X}$ as vir woord $\mathrm{Y})$ ? Hoe kan ons sulke ongelyke datastelle normaliseer om hulle wel vergelykbaar te maak?

- Hoe kan ons die betroubaarheid van hierdie data aan die hand van ander bronne verifieer? Byvoorbeeld, die selfgerapporteerde frekwensies kan met korpusdata vergelyk word om te bepaal of die verskille tussen woorde ook in ander data gereflekteer word.

- Die verskil tussen die taboewaarde vir die self teenoor die taboewaarde vir ander mense is nie verrassend nie: Mens sal geneig wees om te sê dat hulle minder aanstoot sal neem as ander mense. Is daar dalk ander maniere as selfrapportering wat 'n mens kan gebruik om die taboewaarde van woorde meer akkuraat te bepaal?

- Tot slot, hoe kan hierdie insigte uit die data geoperasionaliseer word om van praktiese waarde te wees, byvoorbeeld vir uitgewers, film- en TV-vervaardigers, regsgeleerdes, en so meer?

\section{ERKENNING}

Finansiële ondersteuning deur die Suid-Afrikaans Akademie vir Wetenskap en Kuns maak hierdie navorsing ten dele moontlik. Die in natura-bydraes van BlueTek Computers, WatKykJy. co.za, Afrikaans.com en Maroela Media word ook hiermee met dank erken. Dank ook aan die Woordeboek van die Afrikaanse Taal (WAT), Handwoordeboek van die Afrikaanse Taal (HAT) en die Sentrum vir Tekstegnologie (CTexT) van die Noordwes-Universiteit wat materiaal uit hulle onderskeie databasisse met ons gedeel het.

Verskeie medewerkers en studente werk aan verskeie aspekte van die projek en hierdie navorsing spesifiek; hulle name verskyn by https://vloek.co.za/oor-ons.

\section{BELANGEVERKLARING}

Ten einde die navorsing ten beste te operasionaliseer, is daar in oorleg met die NoordwesUniversiteit besluit dat 'n onafhanklike projekwebblad vir die projek opgerig en onderhou word. Dié webblad, vloek.co.za, is ontwikkel en word besit deur Viridevert NPC (2016/411799/08), 'n maatskappy sonder winsbejag wat by die SAID geregistreer is as 'n opvoedkundige openbare weldaadsorganisasie (OWO) met belastingvrystelling ('n sogenaamde “artikel 18(a)-maatskappy") en met 'n eie bankrekening by FNB. Gerhard B van Huyssteen is een van die direkteure van die maatskappy.

\section{ETIEKKLARING}

Die projek se oorhoofse etiekklaring is op 21 Mei 2019 by die Noordwes-Universiteit se Language Matters Ethics Committee geregistreer; die registrasienommer is NWU-0063219-A7. 


\section{BIBLIOGRAFIE}

Allan, K (ed.) 2019. The Oxford Handbook of Taboo Words and Language. Oxford: Oxford University Press.

AWS ${ }^{4}$ : Boshoff, SPE, Bosman, DB, Le Roux, TH \& Malherbe, DF., in opdrag van die Suid-Afrikaanse Akademie vir Taal, Lettere en Kuns. 1931. Afrikaanse woordelys en spelreëls. 4e uitgawe. Bloemfontein, Kaapstad \& Stellenbosch: Nasionale Pers.

Beers Fägersten, K. 2007. A sociolinguistic analysis of swearword offensiveness. Saarbrücken: Universität des Saarlands. https://www.researchgate.net/publication/265009714_A_sociolinguistic analysis of_swearword_offensiveness [22 August 2021].

Beers Fägersten, K. 2012. Who's Swearing Now? The Social Aspects of Conversational Swearing. Newcastle upon Tyne: Cambridge Scholars Publishing.

Beers Fägersten, K \& Stapleton, K (eds). 2017. Advances in Swearing Research: New Languages and New Contexts. Amsterdam: John Benjamins.

Bergen, BK. 2016. What the F: What Swearing Reveals About Our Language, Our Brains, and Ourselves. New York: Basic Books.

Boshoff, SPE \& Nienaber, GS. 1967. Afrikaanse etimologieë. Pretoria: Suid-Afrikaanse Akademie vir Wetenskap en Kuns.

Calitz, FC. 1979. Spot, skel en verwante verskynsels in Afrikaans. PhD-proefskrif. Stellenbosch: Universiteit Stellenbosch.

Coetzee, F. 2018. "Hy leer dit nie hier nie ("He doesn't learn it here"): talking about children's swearing in extended families in multilingual South Africa." International Journal of Multilingualism, 15(3): 291-305.

Colleman, T. 2015. Constructionalization and post-constructionalization: The constructional semantics of the Dutch krijgen-passive in a diachronic perspective. In: Barðdal, J, Smirnova, E, Sommerer, L \& Gildea, S. Diachronic Construction Grammar. Amsterdam: John Benjamins, pp. 213-255.

Colleman, T. 2016. A reflection on constructionalization and constructional borrowing, inspired by an emerging Dutch replica of the 'time'-away construction. Belgian Journal of Linguistics, 30:91-113.

Dekker, L. 1991. Vloek, skel en vulgariteit: Hantering van sosiolinguisties aanstootlike leksikale items. Lexikos, 1:52-60.

De Vries, J. 1971. Nederlands Etymologisch Woordenboek. Leiden: Brill.

De Vries, M, Te Winkel, L A e.a. 1864-1998. Woordenboek der Nederlandsche taal. 's-Gravenhage: Martinus Nijhoff.

De Vries, W. 1915. Etymologische aanteekeningen: feeks. Tijdschrift voor Nederlandse Taal- en Letterkunde, 34:10.

Eiselen, ER \& Van Huyssteen, GB. 2021. Using ordinal logistic regression to analyse self-reported usage of, and attitudes towards swearwords. Proceedings of the International Conference of the Digital Humanities Association of Southern Africa 2021, 29 November to 3 December, DHASA, South Africa.

Endresen, A \& Janda, LA. 2017. Five statistical models for Likert-type experimental data on acceptability judgments. Journal of Research Design and Statistics in Linguistics and Communication Science, 3(2):217-250.

Enghels, R \& Garachana Camarero, M. 2021. Grammaticalization, Lexicalization, and Constructionalization. In: Wen, X \& Taylor, JR (eds). The Routledge Handbook of Cognitive Linguistics. New York: Routledge, pp. 314-332.

Feinauer, AE. 1981. Die taalkundige gedrag van vloekwoorde in Afrikaans. MA-verhandeling, Stellenbosch: Universiteit Stellenbosch.

Heckathorn, DD. 1997. Respondent-Driven Sampling: A New Approach to the Study of Hidden Populations. Social Problems, 44(2):174-199.

Hilpert, M. 2013. Constructional change in English: Developments in allomorphy, word formation, and syntax. Cambridge: Cambridge University Press.

Jay, T. 1992. Cursing in America: A psycholinguistic study of dirty language in the courts, in the movies, in the schoolyards and on the streets. Amsterdam: John Benjamins.

Jay, T. 2000. Why we curse: A neuro-psycho-social theory of speech. Amsterdam: John Benjamins. 
Köbler, G. 2014. Altsächsisches Wörterbuch. 5th ed. http://www.koeblergerhard.de/ aswbhinw.html [10 September 2021].

Liebenberg, H, Lubbe, J, Cloete, A, Jordaan, A \& Van Wyk, G. 2003. Etimologiewoordeboek van Afrikaans. Stellenbosch: Buro van die Woordeboek van die Afrikaanse Taal.

Luther, J, Pfeiffer, F \& Gouws, RH (reds.). 2015. Handwoordeboek van die Afrikaanse taal. 6e uitgawe. Kaapstad: Pearson.

Lyngfelt, B, Borin, L, Ohara, K \& Torrent, TT (eds). 2018. Constructicography: Constructicon development across languages. Amsterdam: John Benjamins.

McWhorter, JH. 2021. Nine nasty words: English in the gutter: then, now, and forever, Kindle ed. New York: Penguin.

Munzner, T. 2015. Visualization Analysis and Design. Kindle ed. AK Peters Visualization Series. Boca Raton: CRC Press.

O'Driscoll, J. 2020. Offensive Language: Taboo, offence and social control. London: Bloomsbury.

Philippa, M, Debrabandere, F, Quak, A, Schoonheim, T \& Van der Sijs, N. 2003-2009. Etymologisch Woordenboek van het Nederlands. 4 volumes. Amsterdam: Amsterdam University Press.

Pizarro Pedraza, A. 2018. Linguistic Taboo Revisited: Novel Insights from Cognitive Perspectives. Cognitive Linguistics Research [CLR]. Berlin: De Gruyter Mouton.

Pokorny, J. 1959 [2007]. Indogermanisches etymologisches Wörterbuch: An Etymological Dictionary of the Proto-Indo-European Language. Bern: Francke.

Rasinger, SM. 2008. Quantitative research in linguistics. London: Continuum.

Scheepers, R. 2021. "Riana Scheepers borg die woord: feeks". Facebookplasing, https://www.facebook. com/diewoordeboek/posts/10159460135944085 [22 August 2021].

Schiller, K \& Lübben, A. 1875. Mittelniederdeutsches Wörterbuch. Volume 5. Bremen: J. Kühtmann.

Traugott, EC \& Trousdale, G. 2013. Constructionalization and constructional changes. Oxford: Oxford University Press.

Van der Merwe, HJJM. 1971. Vroeë Afrikaanse woordelyste. Pretoria: JL van Schaik.

Van der Veen, KF \& Boer, RD (reds.). 1984-2010. Wurdboek fan de Fryske taal / Woordenboek der Friese taal. 25 volumes. Ljouwert/Leeuwarden: Fryske Akademy.

Van der Walt, A. 2019. Linguistiese eienskappe en konvensionalisering in Zefrikaans op die WatKykJy?blog: 'n korpuslinguistiese ondersoek. MA-verhandeling. Vanderbijlpark: Noordwes-Universiteit.

Van Huyssteen, GB. 1996. The sexist nature of sexual expressions in Afrikaans. Literator, 17(3):119135.

Van Huyssteen, GB. 1998. Die leksikografiese hantering van seksuele uitdrukkings in Afrikaans. South African Journal of Linguistics, 16(2):63-71.

Van Huyssteen, GB. 2019. Vloek Afrikaanssprekendes regtig? Betroubaarheid van 'n eerste grootskaalse meningspeiling se resultate. Vloek.co.za. https://vloek.co.za/blogs/navorsing/vloekafrikaanssprekendes-regtig [16 Augustus 2021].

Van Huyssteen, GB. 2021. Swearing in South Africa: Multidisciplinary research on language taboos. International Conference of the Digital Humanities Association of Southern Africa 2021, South Africa, 29 November to 3 December.

Van Sterkenburg, PGJ. 2019. Rot lekker zelf op: Over politiek incorrect en ander ongepast taalgebruik. Schiedam: Scriptum.

Van Veen, PAF \& Van der Sijs, N. 1997. Etymologisch woordenboek: de herkomst van onze woorden. 2e uitgave. Utrecht/Antwerpen: Van Dale Lexicografie.

Van Wijk, N. 1936 [1912]. Franck's Etymologisch woordenboek der Nederlandsche taal. 2e uitgave. Den Haag: M. Nijhoff.

Verwijs, E \& Verdam, J. 1885-1929. Middelnederlandsch Woordenboek (MNW). 6 volumes. 's-Gravenhage: Martinus Nijhoff.

Von Fallersleben, H. 1845. Niederländische Glossare des XIV. und XV. Jahrhunderts nebst einem Niederdeutschen. Leipzig: Engelmann. 